\title{
RESEARCHING THE SPIRIT OF PLACE. MENTAL MAPPING ON SZIGET FESTIVAL
}

\author{
VIKTÓRIA PAP
}

\begin{abstract}
This paper deals with the atmosphere of Sziget Festival. My research goal was to interpret and to depict the festival as a socio-cultural environment, an experienced material and spiritual space; a special place that exists only for a week. Based on the results, the mental places of Sziget Festival - i.e. the places that exist in festivalgoers' minds - and the most important values of the venue, the functions of the sites, the forces that create places, the most characteristic atmospheric elements of the place, and the channels of perception of the spirit of place can be described. The applied objective of the research was also to assist in festival development, from the perspective of the formation of the festival image and marketing communication to practical considerations. Thus, the research highlights the usability of both the social sciences and applied research (marketing and market research) of genius loci, and some appropriate methods.
\end{abstract}

KEYWORDS: spirit of place, spatiality, mental mapping, experience research, festival research

"Participants should - first and foremost-be offered experiences, this builds the brand best. An appealing venue and an excellent atmosphere are just as important as the music."

(A Sziget ellenfelei [The rivals of Sziget] In: Forbes, June 2016, p. 48.)

1 Viktória Pap is a Ph.D candidate at Corvinus University of Budapest, Institute for Sociology and Social Policy, and by profession is a customer insight manager (researcher); e-mail: viktoriapapv@ gmail.com 


\section{INTRODUCTION}

The present research ${ }^{2}$ deals with the atmosphere of Sziget Festival, describing the mental places of the festival -i.e., of Sziget-goers - and its most characteristic atmosphere-related elements, the channels of the perception of the spirit of place, the invisible functions of the sites, and the forces that create places. The results, based on information obtained from participant observation, provide an opportunity to create a deeper understanding of the concept of the spirit of place, as well as - due to the method of mental mapping - to depict the results on a map.

The research started in 2014 when I participated as researcher for the first time at the festival for a week day and night. That year was the foundation of the exploratory research described in this paper. At that time, I conducted introspective participant observation which involved describing my assimilation and my changing attitudes at the festival.

My most fundamental observation was that Sziget was in fact a unique world where there existed an atmosphere characterized by a variety of features and circumstances which was difficult to describe but easy to live through intensely. Indeed, at Sziget, almost every corner and place has a unique character. In the summer of 2015 I attempted to explore this deeply elusive phenomenon; that is to say, to explore and deepen my understanding of the spirit of the place, which I continued in 2016.

My research from 2015 onwards had an applied research goal in terms of how it provided support for the development of the festival, from the formation of marketing communication (experience) to practical considerations (efficiency). Thus, the results indicate the direction of the application of a concept and methods that can be used in the study of both marketing communications and market research.

\section{ABOUT SZIGET FESTIVAL}

Sziget Festival, held every August for a week, is one of the biggest music festivals and cultural events in Europe, and has won the title of Europe's Best Major Festival twice. The event, which is organized in Budapest on an island [Hajógyári-sziget or Óbudai-sziget] in the Danube, is Hungary's biggest festival

\footnotetext{
2 Our research team, in cooperation with Corvinus University of Budapest and Babes Bolyai University, supported by Sziget Cultural Management Ltd., was present at the festival for the fifth time in 2018 (primarily in the form of a cultural anthropological expedition).
} 
and tourist attraction; it has been organized each year since 1993 and has become increasingly successful and international. It is now one of Hungary's "image elements" that attracts the most foreign tourists. The festival has a budget of $€$ 25 million, and in 2017 hosted more than 450 thousand visitors. ${ }^{3}$

Sziget Festival has fifty program locations, including five major music stages. It can be argued that the festival is very varied regarding both its music and program offers. In addition to mainstream performers, music shows include world music, blues and jazz performances but also electronic music performances which attract a special subculture. Besides music, one can also find children's programs, the stalls of various social organizations and associations, and also literature, dance, fine arts, and sports. Over the last decade, the event has become increasingly commercialized, so today many sponsors and brands are present. In the visually colourful festival, the organizers have created a unique decorative concept of the "Art of Freedom," which means the placement of colourful, extravagant "eye candy" and a program location called the Artzone. The "Island of Freedom" concept has been present in marketing communications since 2013, and was changed by the organizers to the "Love Revolution" theme in 2018.

According to 2017 check-in data (i.e. demographic data about entry to the Sziget Festival), 56 percent of visitors were non-Hungarian. The most populous nationalities were Dutch, French and German, but the website of the festival is currently available in 12 languages. Sixty-seven percent of visitors were in the 18-30 age group, meaning that the main target group is predominantly people in their twenties.

A questionnaire survey of 1207 people carried out by Ipsos in 2017 for Sziget Cultural Management Ltd. revealed that 74 percent of festival participants were college or university students or graduates. The proportion of this group has increased significantly over recent years. Visitors were in a relatively good subjective financial position in terms of their purchasing power. Fifty-six percent of all respondents were able to comfortably make a good living and save up, according to their own declarations. ${ }^{4}$

\section{THE THEORETICAL BACKGROUND TO "GENIUS LOCI"}

Literature that deal with the spirit of place cannot be considered a coherent conceptual unit. On the one hand, it can be said that the topic covers a very wide range of scientific areas - from humanistic geography (see e.g. Pocock, 1981)

3 https://en.szigetfestival.com/sponsors (02.04. 2018)

4 See more: https://en.szigetfestival.com/sponsors 
through literary theory, architecture and environmental psychology to sociology and even settlement marketing; on the other hand, although the origin of the concept dates back a long time, its utility in the social sciences has not yet matured (Jankó, 2002). The spirit of place is an abstract phenomenon which is difficult to grasp, define and conceptualize. Due to this fact, any social researcher who would like to deal with this topic faces a serious yet beautiful challenge.

The distinction between space and place is based on the ideas of ancient philosophers. For example, Aristotle's theory of categories, Descartes's and Newton's absolutist concepts, Leibniz's relative theory of space, and Kant's a priori concept of space. In the nineteenth and twentieth centuries social scientists also began to work on the issue. Their ideas form, as a whole, the social constructivist trend towards "spatiality." The postmodern, so-called trialectic trend towards spatial theoretical concepts (see e.g. Berki, 2015) distinguishes three aspects of spatiality. The first of these is space as we perceive it (perceived space); that is, the space measurable on maps. The second is space as we think of it (conceived space); that is, mental, cognitive space (see e.g. Lynch, 1960; Hall, 1966). The third is space as we experience or use it (lived space); namely, the reality experienced by the subject at a particular moment (smells, colors, lights, sounds, states of mind, etc.). This is the individual experience itself, a subjective experience, a set of individual impressions. In my interpretation, this is the reception and experience of the spirit of place. In Beck's view (1967), these trialectics are divided into objective space (namely, the mathematically descriptive space), ego space (the space of individual psychological operations), and immanent space (the inner, subjective space of the world of representations). The spatial concept associated with Lefebvre (1974) and Soja (1989) emphasizes the subjective perception of space. The former authors distinguish the space we experience, along with perceived space, from conceived space.

Today, the experience society, digitized space usage, and the smart city movement capture space sensations in two important dimensions: efficiency and experiences. There is growing demand for research into how people psychologically perceive the environment. For example, Daniele Quercia, a Spanish computer scientist, presented a so-called Happy Maps application in a TED presentation ${ }^{5}$ which not only focuses on desired routes with a concentration on efficiency, but also takes into account how users like to feel that they are on the move. The application builds on geo-tagged images and uses related metadata to create an alternative form of mapping wherein sites are - in a way - weighted according to human emotions.

5 https://www.ted.com/talks/daniele_quercia_happy_maps (02.04. 2018) 
From an environmental psychological perspective, spatial identity serves to clearly identify place. Physical environments with an identity are able to summon up a specific picture in the observer that is generated by the sum of the effects of sensory organs and which is formed by the subjective perceptions of the individual. Location experience and space sensation is a multichannel process. Sensing the atmosphere of a place affects individuals through various sensory channels. Space sensation is both a physical and an emotional process of interaction that occurs between the individual and the environment. Yi Fu Tuan (1974) defines the sense of space as the personal, psychological and emotional attachment to a given environment. This "bondage" is the love of place, or topohilia.

Theorists who deal with spatial concepts emphasize the multi-sensory nature of spatial experiences. According to Tuan (1977), the experience of location is realized through the synaesthesic interaction of all senses. In his concept of sensory vision, touching, hearing and smelling are taken into consideration. However, Kinayoglu (2009) points to the primary role of vision. Some locations may be better characterized by sounds or odour than, for example, colors. In environmental psychology, the overwhelming dominance of visual perception over other forms of perception is caused by the hierarchization of the distance between the recipient and the subject of perception. Vision is thought to be the most spatial, and therefore the most influential channel of perception. Hearing, touching, smelling and tasting are more intimate channels and are less spatial than vision due to the shorter distances of the stimuli from the perceiver (Rodaway, 1994).

It can be said that different activities require different types of locations. The nature of a site determines the general, comprehensive atmosphere that is to some extent dependent on time. This may involve changes, for example, in seasons, weather or daylight. These factors influence light conditions the most (Norberg-Schulz, 2004).

A place is therefore a distinctive space. Space is formed into a number of individual experiences and thus becomes place. In addition to its physical properties, related experiences and emotions are also constituent elements of places (Dúll, 2002).

My definition - in line with the research field, and based on the literature review - is the following: The spirit of place (genius loci) is the atmosphere, mood and emanation of a geographically/spatially identifiable area (with a name, purpose or function) that can only be perceived through experiences locally. The most important elements in this definition are, on the one hand, identifiability and uniqueness - that is, that the atmosphere is typical of only that place in that composition. On the other hand, the spirit of place is an effect on a person that 
the subject only senses locally. That is, the spirit of place is a mental perception of subjective experiences and emotions closely related to space. Related issues can thus be approached by investigating the mental representations of subjects.

\section{EXPERIENCE RESEARCH}

One of the most popular focus of marketing strategies today is on the implicit, all-pervading delivering, or rather staging experiences, which approach has a clear competitive advantage in the market. ${ }^{6}$ Although experience in the case of festivals in the entertainment industry is explicit, its involvement in market research is also crucial. Tourism as an experience industry creates the conditions for gathering experiences, but the experience is created in the subject (Kovács, 2014). The circumstances in which such experience is acquired (e.g. place, time) and the subject itself therefore both constitute determining factors.

For more than two decades, international literature has focused (even more intensively since the publication of Experience Society by Schulze [1992]) on the socio-economic background of experience. The "experience economy" as a new era was coined by Pine and Gilmore (1998). In their description, experience is an economic category with an epoch-making power which is the successor to the service economy.

The marketing of the digital age places great emphasis on experiencecentred, customer-focused developments. This is also proven by the fact that there are countless terms for experiences in the professional language: product experience, service experience, brand experience, user experience, consumer experience, customer experience, experience design, etc.

The concept of user experience has been defined primarily in the context of digital device and internet use. According to Solis's (2015) equation (besides the basic theory that customer experience $=\$$ ), an experience (henceforth, $\mathrm{X})$ consists of customer experience, user experience, and brand experience $(\mathrm{X}=\mathrm{CX}+\mathrm{UX}+\mathrm{BX})$.

The $\mathrm{X}$ includes all contacts between the client and the company. During experience research, professionals investigate what kind of feelings people have during their interaction with brands, products, and services. This means that experience research actually deals with mapping feelings and thoughts.

Since X concerns people, feelings and thoughts, its definition and research strongly build on psychology and anthropology. The methods that are primarily

\footnotetext{
6 Based on the author's experiences and expertise in the field of market research and customer insight management.
} 
involved in experience research include fieldwork, observation, mystery shopping, user interviews, exit interviews, a variety of product tests, and metrics such as the so-called Net Promoter Score (NPS) - an indicator of user satisfaction that shows in a standardized way to what extent the product and service would be recommended by those who know the product or service to others.

Although during an experience design process mapping may be used as a tool, such as for describing and planning processes (mind mapping) and so-called customer journeys, mental mapping as a method has been less used in market research for investigating space-related customer experiences. In this paper I present mental mapping as an appropriate method for use in marketing-oriented research into space-related experiences.

\section{RESEARCH GOALS AND QUESTIONS}

The dilemma in the literature that concerns the spirit of place is the connection between space and its parts. That is, if we can talk about the "spirit of place" in the case of a given place, can we do the same for parts of a place? (Jankó, 2002). Considering this important theoretical question, I formulated my main research objective thus: to conduct an investigation of the interpretation and representation of place, namely the socio-cultural environment and lived/ experienced material and spiritual space. This generated five associated research questions in relation to Sziget:

1. What are the characteristic spots?

2. What are the evolving/alternative places, in addition to preexisting/ established venues?

3. What are the forces that create place and form space?

4. What are the determining elements of the atmosphere?

5. What are the channels of perception of the spirit of place?

\section{APPLIED METHODS}

I used three methods to explore and describe the spirit of place. Mental mapping (oriented-recall mental mapping), a questionnaire survey, and participant observation (content analysis of fieldwork logs). My main research method, mental mapping, is an interdisciplinary area that is located at the boundaries of geography, psychology, linguistics and social sciences (for details, see Letenyei, 2006). The other applied methods were designed to complement this method. 
In my interpretation, the spirit of place is perceived as the mental perception of subjective experiences and feelings closely related to place through verbally expressible experience. Therefore, I consider mental mapping to be the most appropriate method for its exploration. In order to reveal the elements of the spirit of place experienced by individuals and visualize the places of the festival, we asked interviewees to indicate their own spaces on a blank map showing the whole Sziget (only the main paths), meaning that they should assign cognitive or emotional buzzwords to their important places (see Figure 1). In fact, we actually drew experience maps with respondents.

Figure 1. A mental map about the experiences of a festivalgoer

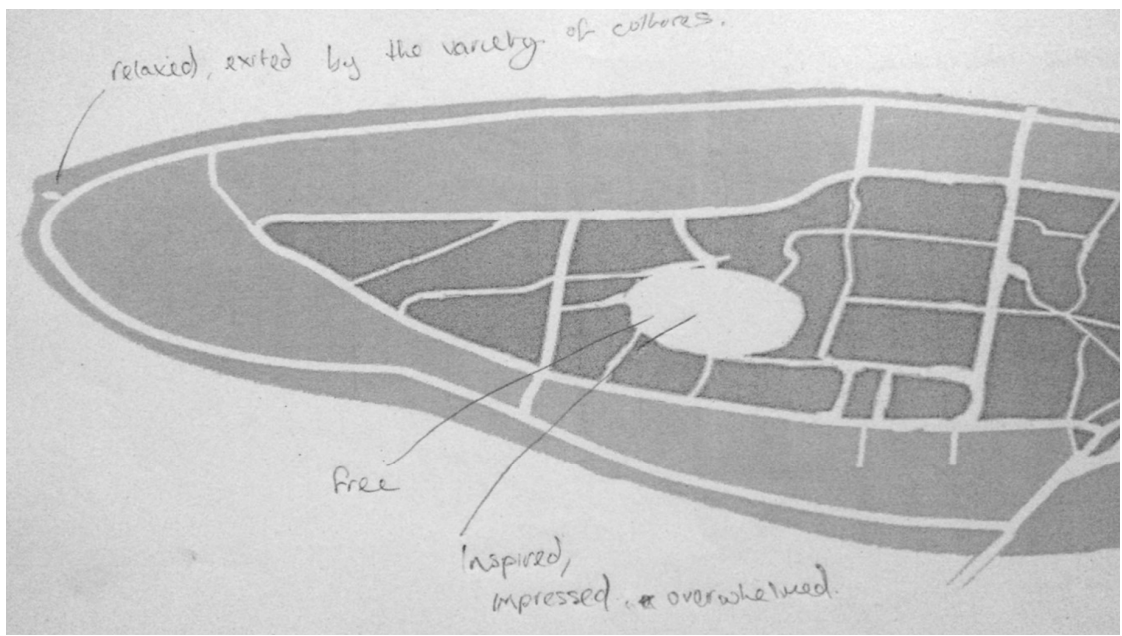

A total of $225\left(\mathrm{~N}_{2015}=95, \mathrm{~N}_{2016}=130\right)$ respondents sketched an experience map after having been chosen via random walk sampling. After processing the maps, the mental places of Sziget could be defined. Regarding the gender distribution of the sample, 59 percent of respondents were women, 41 percent male, while 49 percent were Hungarian and 51 percent non-Hungarian.

The example of mental mapping we employed (namely, experience mapping) was designed especially for researching the spirit of place at Sziget Festival, and was used here for the first time. In 2015, when we used the method for the first time in the field, it was important and useful to draw the experience so that we could use it more effectively next year.

Despite some slight difficulties, the festival proved to be excellent terrain for drawing the experience maps. Those who were asked to participate considered 
the task to be a form of playing, learning, and self-expression, so they responded enthusiastically to the exercise.

However, the interviewers had a difficult task because, although they were not allowed to suggest answers, it was essential that we did not collect program or performers' names, and that we were not inquiring into respondents' satisfaction. In order to facilitate the desired types of replies, field researchers could use helping, periphrastic, leading questions. These included, for example, "What is the place on Sziget that you are most tied to?" (It could be not only a program venue.), and "Where did the most remarkable and memorable events happen to you (whether good or bad)?"

The most common problem was, in spite of the clarifying questions, that experiences and emotions were not often described by the respondents but rather programs, concerts, performances, or levels of satisfaction. The reason for this is that the desired task required a greater degree of creativity and emotional expression which some respondents did not have the appropriate skills for. Undecodable responses were also a challenge; these were clearly due to the characteristics of the terrain, mainly a lack of concentration. For example, maps with only drawings, unreadable handwriting, or just placemarks were submitted.

We recorded the gender and nationality of respondents on the back of the maps and asked questions to gather supplementary information, including how many times the respondents had been to Sziget and how many days they had spent there that year. The spiritual and emotional intensity of the perception of place is dependent on individuals, their cognition, knowledge, state of mind, and mood, but also significantly on the amount of time they spend at a location; that is, assimilation (Jankó, 2002). Therefore, we started the query in both years only from the third day of the festival. In the middle of festival week there were spectacularly fewer experiences on the cards than at the end of the week. Before starting the fieldwork, Sziget was divided up in terms of areas among the interviewers and we also paid attention to addressing respondents at various times of day. Researchers were asked to record the exact time and location of the interview on the back of each map. On the last day, I also asked each of the participating researchers to draw their own experience maps, which I also included in the analysis.

Responses on a map contain a lot of information for the researcher, not only in terms of content but also visually. Mapping, spatial vision and representation are obviously subjective. This claim is supported by the fact that there were respondents who, compared to most of the respondents, drew their experiences on a blank map from a perspective of 90 or 180 degrees.

Via the questionnaire survey, I mainly sought answers to two questions: "If asked to describe the atmosphere in one word, what would this be? How 
would you describe the aura?" and "What is the first word that comes to your mind concerning the citizens of Sziget Festival?" The definitive atmosphere of Sziget Festival can be described in one word (i.e. the one-word expression of the spirit of place), as can the emanation of Sziget society (that is, what kind of determining atmosphere the non-material nature of the spirit of place has, and how it contributes to the atmosphere). As Sziget is a special place - a festival society that exists only for one week per year - the important elements of the spirit of place are social elements, which are also personal and subjective mental elements: namely, feelings, associations, and emanations.

These questions were asked as part of a longer questionnaire survey based on random walk sampling. In addition to the two questions, the questionnaire also contained questions about the most important values of the festival, which also provided useful information about the spirit of place. The database containing the answers to the survey questions also included information about the day the questionnaire was filled in and the number of times the respondent had been to Sziget. These are pieces of background information that were used to filter out respondents who were presumably less receptive to the spirit of place. There were 533 respondents in the questionnaire sample, 44 percent male and 56 percent female, 48 percent Hungarian and 52 percent non-Hungarian. In terms of to age composition, the respondents' average age was 23 years (from 16-49 years old).

The third method I employed was the analysis of fieldwork logs. The texts created by the researchers involved in participant observation (that is, the field logs) also contained elements of the spirit of place without the focus of the authors (i.e. researchers in the field). Content analysis can help researchers to obtain relevant information that is observable but which is more difficult to grasp. This method is the least intrusive of the three I employed. In this fieldwork sample, there were 30 individuals (Hungarians and cross-border Hungarians), of whom 43 percent were male and 57 percent female.

In the course of the analysis, I collected the words and phrases regarding the atmosphere-related elements, and created research categories from them. I then supplemented the information derived from the previously analyzed and categorized questionnaires and formerly mapped information. Although most of the journals were written on a daily basis, the analysis was broken down on an individual basis. The analytical unit of encoding is the reception channel, which procedure was carried out with the so-called open coding technique (see e.g. Strauss - Corbin, 1998). Without the mentioned frequencies, every relevant, at least once-recurring term was included in the category system. The result of the analysis was a concept map that presents the elements of the spirit of place and the channels of reception in Sziget Festival that organizes experiences, feelings and attitudes into a structure. 


\section{RESEARCH OUTCOMES}

\section{Places and mental spaces}

After processing the maps, three sites outside the Sziget area became identifiable (see Figure 2). These can be considered the foregrounds of Sziget. It can be seen that the festival as a place in terms of mental space extends outside its geographical boundaries. These outlying places are an Auchan hypermarket, a section of road with cordons (the "check-in path" to the different check-in stations that we call the "baffle in"), and the so-called K-Bridge which is considered to be the main gateway to the festival. From these, Auchan was considered the most significant. On the one hand, this is due to the frequency of mentions and experiences, but also because it is the farthest and most differentiated place which mentally forms a part of the Sziget area, thus its atmosphere is seen as part of the festival. The most important buzzwords related to it are "cheap," "booze" (alcohol) and "food." Based on the maps, it can be said that the K-Bridge and the queue there are almost everybody's remarkable first experience. Here the most striking expressions were "excitement" and "joy."

Further analysis of the maps made several alternative so-called mental places identifiable. Seventeen places can be specified based on the experience of specific venues (e.g. A38, Volt, Luminarium, Snowattack, Magic Mirror, Cirque du Sziget) and ten places that formed spontaneously - for example, shared mental places at the border of several locations were identified on mental maps in both years. Among the latter, as a shared area of experience and function we can highlight the information distribution area, the "info spot" intersection beyond the K-Bridge, or what we call "Colosseum Square," which is bordered by the triangle of the Colosseum electronic music venue, a swing installation and the Aréna party tent. The former is notable because of the tobacco shop, Festipay, its meeting point functions, and the large amount of dust or mud that is mentioned; the latter because of the non-stop parties and "party faces."

The most important sites - i.e. the sites mentioned by most individuals and the most experience associated with them - are the Main Stage and the Beach-Chill area. It can be seen that Sziget has two important basic functions and thus basic forms of atmosphere: partying and vacationing.

The mapping of the experience clearly identifies the most characteristic places as well as the places that might be called "islands on Sziget" (the latter word meaning "island" in English, thus "islands on the Island"). The latter are typical for being somewhat external to the general atmosphere of the island, yet they add something to it overall. Thus, for example, the Boathouse has become a special place primarily because of its Hungarian identity, because it is the only place 
where cash payment is an option, and because it is where the only English-style toilet is accessible. "VIP," for example, is a place whose atmosphere-related elements can be found in the descriptions contained in the field logs:

“... a celeb can come to Sziget to be somewhere else and won't get dirty.

It is good to be here, too, but in a different way."

In the case of the most characteristic places, however, special markers and experiences that cannot be observed elsewhere make them remarkable and notable, but do not distinguish them from the general atmosphere of the entire Sziget Festival. These include, for example, the Magic Mirror, the Beach, the Colosseum Square and the Cirque du Sziget.

A total of 10 routes from the tangled road network appeared on the experience maps. These markings may refer to small places on roadsides or on-road experiences. After specifying mental spaces, places defined by the experiences, and the most exciting paths on a map, an experience map of Sziget Festival may be drawn.

Figure 2. Visitors' mental places on Sziget Festival ( $N=225)$

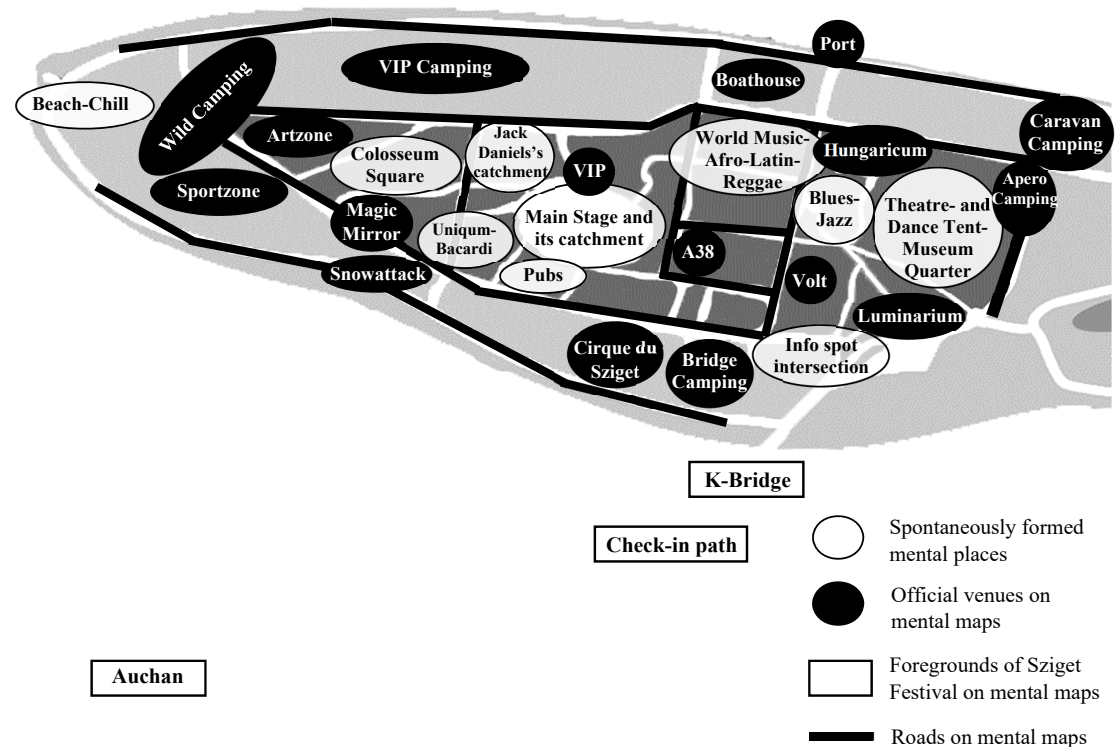


Based on the results of the maps, it can be said that space-forming forces on Sziget basically relate to the following: 1. sleeping, 2. music, 3. eating, 4 . alcohol, 5. coolness/shade, refreshment and relaxation, 6. meeting others, 7. dust and mud. Personal, subjective experiences are space-forming forces that affect mental places. Thus, these are all the invisible functions of places that can be recognized directly from a field exploration perspective. It thus appears that exploratory research of this kind can generate important applied research results and contribute to practical considerations about efficiency as well.

\section{The elements of the Sziget Festival atmosphere}

When writing their experiences on a blank map, some people noted their experiences and impressions about the whole of Sziget. These are clearly the atmosphere-related elements that can be linked to the spirit of place:

"happiness, remaining, peaceful place in the world, freedom of expression"

"Sziget is something like no other $<3$ "

According to the questionnaire survey, respondents said that the most characteristic elements of the atmosphere were freedom, friendliness, craziness, and relaxation/ chill (see Figure 3). While there is fatigue and exhaustion during the week, there is also so much relaxation and "chill." Sziget is seen both as non-stop party, but also a time for resting and vacation. It is also apparent that weather-related atmosphere elements (e.g. dust and heat) are also important in the experience of place.

Figure 3. Word cloud of Sziget atmosphere, with mood indicated in one word $(N=480)$ "How would you describe the mood in one word? How would you describe the atmosphere?"

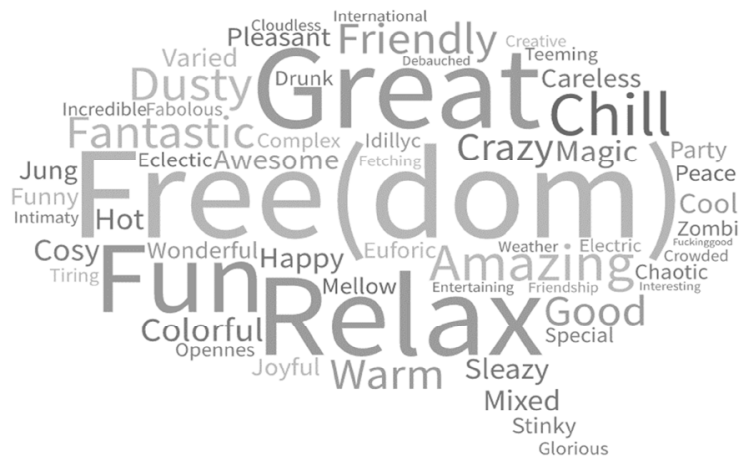

CORVINUS JOURNAL OF SOCIOLOGY AND SOCIAL POLICY VOL. 10 (2019) 1 
The spirit of place on Sziget is the factor which determines community. The most characteristic features of the people on Sziget are openness and friendliness, according to respondents' answers (see Figure 4). An important feature of Festival society is its international nature, colourfulness, and multiculturalism, but craziness and wildness are also considered characteristic traits.

Figure 4. Word cloud of Sziget population described using one word ( $N=470)$

"What is the first word you would use to describe the people at Sziget?"

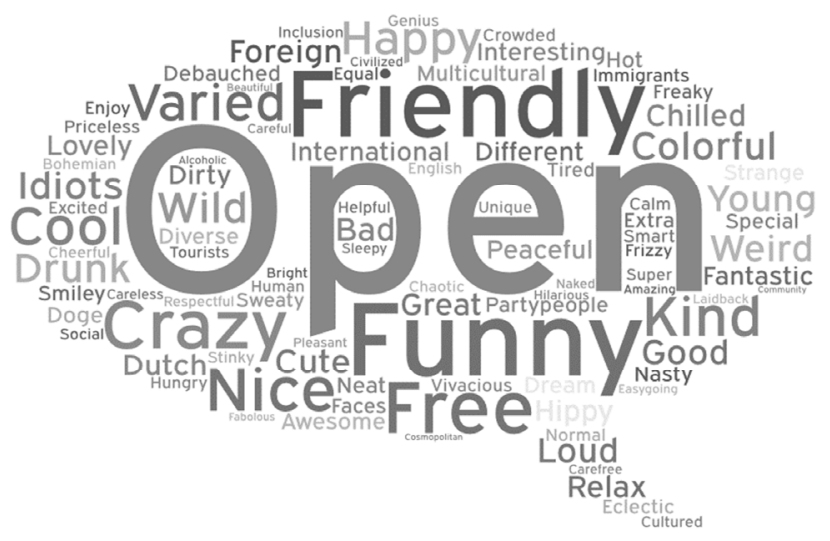

The most important values of Sziget can be classified into twelve groups according to the answers to the question "What are the most important values of Sziget Festival?" (see Table 1). Among the answers, the values associated with the unique atmosphere and the place as a typical location can be classified into a separate category. 
Table 1. "In your opinion, what are the most important values of Sziget Festival?" (N=533)

\begin{tabular}{|c|c|c|}
\hline Value groups & Frequency & Examples \\
\hline music, line up, artists, concerts, bands & 128 & "multifaceted" \\
\hline community, relationships, friends, people & 102 & "to be together," "many people become one" \\
\hline $\begin{array}{l}\text { equality, diversity, multiculturalism, } \\
\text { internationality, cultural difference, } \\
\text { tolerance, open-mindedness }\end{array}$ & 97 & $\begin{array}{l}\text { "everyone is equal and you can feel free no } \\
\text { matter where are you from" }\end{array}$ \\
\hline freedom, peace, love & 83 & "do whatever," "youcanbewhatever" \\
\hline ambiance, vibe, atmosphere, mood, feeling & 48 & $\begin{array}{c}\text { "interesting fake realities," "it is a special } \\
\text { world here" }\end{array}$ \\
\hline fun, have good time, party & 47 & "high quality entertainment" \\
\hline the place, location & 31 & $\begin{array}{l}\text { "walking area," "that you can camp } \\
\text { inside," "easy to camp anywhere," "dome," } \\
\text { "Budapest," "escape bubble," "being away } \\
\text { from everything" }\end{array}$ \\
\hline art, theatre, circus, culture & 24 & $\begin{array}{l}\text { "not just music and drinking, there are other } \\
\text { programs }\end{array}$ \\
\hline relax, chill, no stress, don't worry, be careless & 12 & "loose and switched off" \\
\hline decoration & 8 & "creative decoration" \\
\hline food, beverages & 5 & "good food" \\
\hline weather, timing & 3 & $\begin{array}{c}\text { "a week long," "the timing, the middle of } \\
\text { August is perfect for festivals" }\end{array}$ \\
\hline
\end{tabular}

From 533 respondents, 48 respondents gave a value indicator to the unique atmosphere of Sziget Festival. Considering the frequency of the value groups, in addition to the program offering, the values of the Sziget population are considered to be of the greatest significance and value.

\section{The channels of perception}

Information about the atmospheric elements of Sziget Festival obtained through the three methods can be classified into categories of perception. The elements structured this way can be divided into two main categories (see Figure 5). These are sensory experience (material and physical elements) and intersubjective experience (social elements); that is, the characteristics associated with local being. The latter can be divided into two distinct subcategories. On the one hand, there are those elements that refer to ideologies and values, and on the other those that refer to lifestyle and behaviour. Concerning sensory experience, four of the five sensory perceptions are clearly identifiable with 
respect to Sziget Festival, while the fifth one, touch, arises within a group called weather. Here, it is not possible to classify all of these experiences into a single perception. For example, "rain" or "dust" can refer to the receipt of experience through sight, touch or even smell.

Figure 5. Concept map-Constituents of the spirit of place according to the channels of perception on Sziget Festival

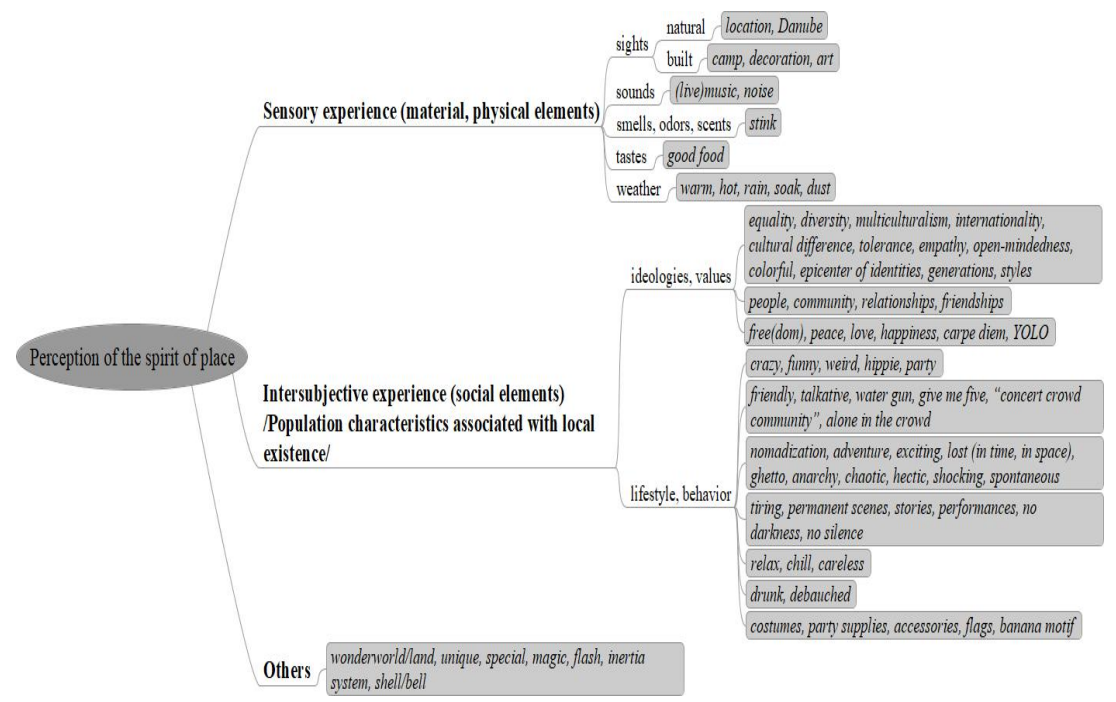

* The figure is based on information obtained via the three analytical methods

In addition to the two main areas of "receptions" (sensory and socio-cultural reception channels), there is also a group into which more abstract experiences are classified that cannot be placed into any other category. This mostly includes adjectives for the place as a whole, may indicate tangible and intangible experiences and sensations.

\section{CONCLUSION}

A festival which is geographically distinct exists far beyond its spatial and physical boundaries. The atmosphere of the event and the experiences associated with it outline the place more clearly than objective, physically tangible, measurable boundaries. In the case of Sziget Festival, the event venue 
is a special, isolated area surrounded by water. However, even outside the defined area of Sziget, places closely related to the atmosphere of the festival can be identified. Beyond these, one can identify not only the experiences that are connected to official sites, but also those that are spontaneously created. The forces that create places at the festival prevail along natural and cultural conditions. Although some sites emerge that are indirectly and unconsciously the result of organization, they are still defined by the individuals who use them and the recipients and the functions that are created, which by their very nature can only be seen from the bottom and very close up.

The most important natural factors pertaining to atmosphere are weather conditions (shade, dust, mud) and the location itself (Danube Island). In the field of cultural characteristics, it is not only activities which meet basic needs (such as sleeping or eating) which are considered essential, but music and meeting are also of primary importance in the creation of place.

Thus the festival as a "place of experiencing" is made up of a combination of several places and venue-defined atmospheres. There are places that stick out, but which still emblematically form a part of the Sziget atmosphere. If they were omitted, the nature of the festival would radically change. Accordingly, identification of the characteristic places or the emerging mental places that are not program places is also important in this respect.

Freedom, art and decoration as marketing themes clearly appear among the elements of the atmosphere. In the case of venues for festivals, place marketing and place branding supported by research might prove to be of great importance. The location itself and its atmosphere provide an experience for visitors (i.e. visitor experience, or VE). As a result, the atmosphere of the place may be considered an essential component of marketing communication and festival development. This is why the involvement of experience research in marketing and market research can provide new information for various forms of business development (commercial-, tourism-related, etc.).

The atmosphere of Sziget has been described as unique by many people. Although we have not undertaken a comparative analysis, the present research suggests that a festival as a periodically created place is able to create its own atmosphere: a spirit of place. 


\section{REFERENCES}

Ács Gábor (2016), “A Sziget ellenfelei” [The rivals of Sziget], Forbes, June 2016, pp. 48.

Beck, R. (1967), "Spatial meaning and the properties of the environment", in: Proshansky, H. M., Ittelson, W. H., Rivlin, L. G., ed., (1970) Environmental psychology: Man and his physical setting, New York, Holt, Rinehart and Winston Inc., pp. 134-141.

Berki Márton (2015), "A térbeliség trialektikája" [The trialectics of spatiality], Tér és Társadalom 2015/2, pp. 3-18.

Bőhm Antal - Táll Éva (1992), Pápa a rezisztens város: Egy kisváros a nyolcvanas évek végén [Pápa, a resistant city: A small town in the late 1980s], Budapest, MTA Politikai Tudományok Intézete

Bott, S. - G. Cantrill J. - Myers O. E. (2003), "Place and the Promise of Conservation Psychology", Human Ecology Review, 2003/10/2 pp. 100-112. Retrieved from http://www.jstor.org/stable/24706959.

Data from Sziget Cultural Management Ltd.: https://en.szigetfestival.com/ sponsors

Dúll Andrea (2004), "Helyek és dolgok: a tárgyi környezet jelentésének környezetpszichológiai megközelítései és mérési lehetőségei" [Places and things: environmental psychological approaches and measurement opportunities in relation to the meaning of the material environment], in: Kapitány Ágnes - Kapitány Gábor, ed., Termékszemantika, Budapest, Magyar Iparmüvészeti Egyetem

Hall, E. T. (1966), The hidden dimension, New York, Anchor Books, pp. 53-77. Jankó Ferenc (2002), "A hely szelleme, a településimage és településmarketing" [The spirit of place, settlement image and settlement marketing], Tér és Társadalom, 2002/4 pp. 39-62.

Kinayoglu, G. (2009), The role of sound in making of a sense of place in real, virtual and augmented environments, $\mathrm{PhD}$ dissertation, Berkeley, University of California

Kovács Dezső (2014), “Élmény, élménygazdaság, élménytársadalom és turizmus" [Experience, experience economy, experience society and tourism], Turizmus Bulletin, 2014/3-4, pp. 40-48.

Lefebvre, H. (1974), The production of space, London, Blackwell

Letenyei László (2006), "Mentális térkép szerkesztése" [Editing mental maps], in: Letenyei László, ed., Településkutatás I., Budapest, Új Mandátum Kiadó - Ráció Kiadó, pp. 147-172.

Lynch, K. (1960), The image of the city, Cambridge, MIT Press

Norberg-Schulz, Ch. (2004), “Genius loci”, Ökotáj, 2004/33-34, pp. 65-75. 
Pine II, B. J. - Gilmore J. H. (1998), "Welcome to the experience economy", Harvard Business Review, 76 (4), pp. 97-105.

Pocock, D., ed. (1981), Humanistic Geography and Literature: Essays on the Experience of Place, London, Croom Helm, https://doi.org/10.1016/03057488(83)90171-8

Quercia, D. (2014), Happy maps, https://www.ted.com/talks/daniele_quercia_ happy_maps

Rodaway, P. (1994), Sensuous Geographies: Body, Sense, and Place, LondonNew York, Routledge

Schulze, G. (1992), Die Erlebnisgesellschaft. Kultursoziologie der Gegenwart [The Experience Society: The Cultural Sociology of the Present], Frankfurt am Main-New York, Campus Verlag

Soja, E. (1989), Postmodern Geographies: The Reassertion of Space in Critical Social Theory, London, Verso Press

Solis, B. (2015), X: The Experience When Business Meets Design, New York, John Wiley \& Sons INC International Concepts

Strauss, A. L. - Corbin, J. M. (1998) "Open Coding” In: Basics of Qualitative Research: Techniques and Procedures for Developing Grounded Theory, Sage, http://dx.doi.org/10.4135/9781452230153

Tuan, Y. F. (1974), Topophilia: a study of environmental perception, attitudes, and values, Prentice-Hall, Englewood Cliffs

Tuan, Y. F. (1977), Space and Place: The Perspective of Experience, Minneapolis, University of Minnesota Press 
